\author{
Stanistaw Prutis ${ }^{1}$
}

\title{
Regulacje prawne produkcji ekologicznej w rolnictwie polskim
}

1. Problemy rolnictwa ekologicznego w doktrynie ekonomiki rolnictwa i gospodarki żywnościowej analizowane i prezentowane są w oparciu o kategorię ,gospodarstwa ekologicznego", podstawowej jednostki wytwórczej w rolnictwie, w której produkcja prowadzona jest z wykorzystaniem metod ekologicznych i której efekt - produkt ekologiczny - dostarczany jest na europejski rynek żywności ekologicznej. ${ }^{2}$ Co jednak charakterystyczne, ani ustawodawstwo Unii Europejskiej, ani prawodawstwo krajowe nie tylko nie definiują pojęcia ,gospodarstwa ekologicznego", lecz w ogóle nie posługują się tą kategorią. W obowiązującym porządku prawnym używa się określeń: „rolnictwo ekologiczne”, „ekologiczna produkcja roślinna i zwierzęca”, ,produkty ekologiczne”, ,produkty rolnictwa ekologicznego”. Stąd też w tytule niniejszego opracowania mowa jest o regulacji prawnej produkcji ekologicznej w rolnictwie.

Czynniki determinujące rozwój i poziom rolnictwa ekologicznego w krajach Unii Europejskiej, w tym w Polsce, są oczywiście bardzo różnej natury. ${ }^{3}$ Są one zróżnicowane także ze względu na intensywność ,elementu” ekologicznego w produkcji rolniczej. Za produkcję ekologiczną uznaje się taką, która prowadzona jest przy maksymalnym poszanowaniu zasad ochrony środowiska, niezależnie od efektów i przeznaczenia produktu finalnego. O finalnym ,produkcie ekologicznym” można mówić w sytuacji, kiedy efekt ekologiczny produkcji rolniczej w postaci produktu końcowego wprowadzony zostanie, z odpowiednim certyfikatem, na rynek żywnościowy. A zatem rolnictwem ekologicznym jest zarówno takie, kiedy sam proces produkcji ma charakter ekologiczny, jak i takie, kiedy wymagania ,ekologiczności" dotyczą nie tylko samej produkcji, ale jej efektu końcowego trafiającego na rynek żywności, jako produkt „eko”, czy „bio”.

Uniwersytet w Białymstoku

Por. przykładowo: T. Nowogródzka, M. Podstawka, S. Szarek: Towarowość a sytuacja produkcyjno-ekonomiczna gospodarstw ekologicznych w Polsce, „Wieś i Rolnictwo” 2013, nr 2, s. 157 i n.

Odsyłam tu do opracowania: A. Kowalska, Czynniki wpływające na rozwój rolnictwa ekologicznego w Polsce i innych krajach europejskich, Annales Universitatis Mariae Curie-Skłodowska Lublin Polonia Vol. XLIV Sectio H, 2010, s. 47-63. 
O rozwoju gospodarstw rolnych wytwarzających produkty ekologiczne decydują w zasadzie prawa rynku. Nieustannie rośnie popyt na certyfikowaną żywność ekologiczną, jednakże w Polsce można spotkać się z opinią, że nasza żywność produkowana $\mathrm{w}$ warunkach konwencjonalnych jest na tak dobrym poziomie, że zakupy w sklepach ekologicznych są snobistycznym ,przepłacaniem”. Informacje statystyczne potwierdzają (patrz zestawienie zamieszczone na stronie następnej), że producenci ekologiczni wprowadzający swoje produkty na rynek produktów ekologicznych stanowią mniej niż $1 \%$ ogółu producentów ekologicznych - 252 producentów rynkowych na ogólną liczbę 26.376 producentów ekologicznych (stan na koniec 2012 roku). Znakomita większość producentów ekologicznych otrzymała ten status ze względu na prowadzenie działalności w zakresie produkcji rolnej w warunkach ekologicznych, niezależnie od standardu samego produktu finalnego (jest to liczba 25.944 producentów ekologicznych). Dzieje się (zapewne) tak dlatego, że samo prowadzenie produkcji rolniczej w warunkach ekologicznych, niezależnie od losów produktu finalnego, jest uznawane za działalność zasługującą na wsparcie finansowe ze środków przeznaczonych na rozwój obszarów wiejskich.

Liczba producentów ekologicznych w Polsce (zestawienie wg stanu na dzień 31.12.2012 r. z rozróżnieniem kategorii prowadzonej działalności ekologicznej)*

\begin{tabular}{|l|c||}
\hline Zakres prowadzonej działalności: & Liczba producentów ekologicznych: \\
\hline produkcja rolna & 25.944 \\
\hline $\begin{array}{l}\text { przetwórstwo produktów ekologicznych oraz } \\
\text { produkcji pasz i/lub drożdży }\end{array}$ & 312 \\
\hline $\begin{array}{l}\text { wprowadzanie na rynek produktów ekologicz- } \\
\text { nych importowanych z państw trzecich }\end{array}$ & 30 \\
\hline $\begin{array}{l}\text { wprowadzanie na rynek produktów ekologicz- } \\
\text { nych (z wyłączeniem importowanych z państw } \\
\text { trzecich) }\end{array}$ & 252 \\
\hline $\begin{array}{l}\text { dostawy kwalifikowanego materiału siewnego } \\
\text { i wegetatywnego materiału rozmnożeniowego }\end{array}$ & 24 \\
\hline pszczelarstwo & 21 \\
\hline zbiór ze stanu naturalnego & 37 \\
\hline akwakultury i/lub wodorosty morskie & $\mathbf{2 6 . 3 7 6}$ \\
\hline Ogółem producentów ekologicznych & \\
\hline
\end{tabular}

* Zestawienie opracowane na podstawie tabeli: Liczba producentów ekologicznych, wg stanu na dzień 31 grudnia 2012 r. w Polsce w podziale na województwa i w podziale na kategorie prowadzonej działalności, zamieszczonej na stronie http://www.ijhar-s.gov.pl 
Do czynników determinujących rozwój rolnictwa ekologicznego należą oczywiście regulacje prawne, będące instrumentem Wspólnej Polityki Rolnej, organizujące i wspierające produkcję ekologiczną. Specjaliści z zakresu ekonomiki rolnictwa i gospodarki żywnościowej wskazując „kamienie milowe” w historii rolnictwa ekologicznego w Polsce, a także w Europie ${ }^{4}$ rolę tych „kamieni” przypisują właśnie kolejnym regulacjom prawnym.

2. Z kronikarskiego obowiązku odnotować należy, że pierwszą regulacją rangi ustawowej w naszym porządku prawnym była ustawa z dnia 16 marca $2001 \mathrm{r}$. o rolnictwie ekologicznym. ${ }^{5}$ Przedmiotem jej regulacji były:

1) warunki prowadzenia produkcji rolnej i przetwórstwa rolno-spożywczego metodami ekologicznymi oraz system kontroli i certyfikacji tej produkcji i tego przetwórstwa,

2) obrót produktami rolnictwa ekologicznego oraz ich znakowanie.

Omawiana ustawa używała pojęcia „ekologiczne gospodarstwo rolne” (w późniejszych regulacjach prawnych konstrukcja ta znika), definiując je jako gospodarstwo, w którym produkcja rolna prowadzona jest metodami ekologicznymi, tzn. zgodnie z zasadą zrównoważonego rozwoju, aktywizuje przyrodnicze mechanizmy produkcji rolnej poprzez stosowanie naturalnych środków produkcji oraz zapewnia trwałą żyzność gleby, zdrowotność roślin i zwierząt. Regulacja tej ustawy była swoistym przygotowaniem polskiego rolnictwa do wejścia do Unii Europejskiej, gdzie obowiązywało już wcześniej ustawodawstwo organizujące produkcję ekologiczną. Omawiana ustawa z 2001 roku utraciła moc na podstawie art. 17 kolejnej ustawy z dnia 20 kwietnia 2004 roku o rolnictwie ekologicznym ${ }^{6}$ - ustawa ta weszła w życie z dniem uzyskania przez Rzeczpospolitą Polską członkostwa w Unii Europejskiej.

3. Od momentu wejścia Polski do Unii Europejskiej regulacje prawne dotyczące ekologicznej gospodarki rolnej przybierają charakterystyczną formę „dwuwarstwową":

1) ustawodawstwo unijne określające ogólne ramy (wspólne cele, zasady i reguły) mające zastosowanie do produkcji ekologicznej,

2) ustawodawstwo krajowe, określające zadania oraz właściwość organów administracji publicznej i jednostek organizacyjnych w zakresie wykonania przepisów unijnych o rolnictwie ekologicznym.

W świetle przepisów unijnych, produkcja ekologiczna jest ogólnym systemem zarządzania gospodarstwem i produkcji żywności, łączącym najkorzystniejsze dla 
środowiska praktyki, wysoki stopień różnorodności biologicznej, ochronę zasobów naturalnych, stosowanie wysokich standardów dotyczących dobrostanu zwierząt z metodą produkcji odpowiadającą wymaganiom niektórych konsumentów preferujących wyroby wytwarzane przy użyciu substancji naturalnych i naturalnych procesów. Ekologiczna metoda produkcji pełni zatem podwójną funkcję społeczną: z jednej strony dostarcza towarów na specyficzny rynek kształtowany przez popyt na produkty ekologiczne, a z drugiej strony jest działaniem w interesie publicznym, ponieważ przyczynia się do ochrony środowiska, dobrostanu zwierząt i rozwoju obszarów wiejskich. ${ }^{7}$

Właśnie, w zależności od funkcji społecznej rolnictwa ekologicznego, na którą położony jest akcent danej regulacji prawnej trzeba wyróżnić dwa nurty ustawodawstwa, a w konsekwencji dwa bloki przepisów dotyczących rolnictwa ekologicznego:

1) Nurt główny, gdzie przedmiotem regulacji przepisów są wszystkie etapy produkcji, przygotowania i dystrybucji produktów rolnictwa ekologicznego oraz ich kontroli.

2) Nurt uzupełniający, gdzie rolnictwo ekologiczne jest przedmiotem regulacji jako element całości, służącej osiągnięciu szerszych celów wspólnej polityki rolnej. Chodzi tu o rolnictwo ekologiczne jako jeden z pakietów wyodrębnionych w ramach działania: „Program rolnośrodowiskowy”, służącego wsparciu rozwoju obszarów wiejskich w ramach osi: „Poprawa środowiska naturalnego i terenów wiejskich”. Celem wsparcia rozwoju rolnictwa ekologicznego w tym przypadku nie jest pozyskanie finalnego produktu ekologicznego, lecz samo prowadzenie ekologicznej produkcji rolnej w ramach zrównoważonego systemu zarządzania rolnictwem, tzn. z maksymalnym poszanowaniem reguł ochrony środowiska.

Od momentu wejścia Polski do Unii Europejskiej główny nurt ustawodawstwa w zakresie rolnictwa ekologicznego tworzyły: rozporządzenie Rady nr 2092/91/ EWG z dnia 24 czerwca 1991 r. w sprawie produkcji ekologicznej produktów rolnych oraz znakowania produktów rolnych i środków spożywczych ${ }^{8}$ oraz ustawa z dnia 20 kwietnia 2004 r. o rolnictwie ekologicznym. ${ }^{9}$ Obowiązujący aktualnie model normatywny rolnictwa ekologicznego ukształtowany został w roku 2009. $\mathrm{Z}$ dniem 1 stycznia 2009 r. weszło w życie rozporządzenie Rady (WE) nr 834/2007 z dnia 28 czerwca 2007 r. w sprawie produkcji ekologicznej i znakowania produktów ekologicznych oraz uchylające rozporządzenie (EWG) $\mathrm{nr} 2092 / 91,{ }^{10}$ natomiast ustawa z dnia 25 czerwca 2009 r. o rolnictwie ekologicznym ${ }^{11}$ weszła w życie

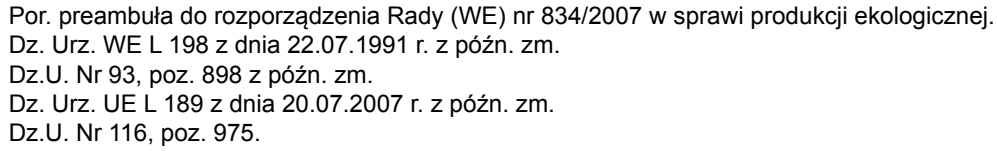


6 sierpnia 2009 r. Krajowe źródła prawa uzupełnia rozporządzenie Ministra Rolnictwa i Rozwoju Wsi z dnia 18 marca 2010 r. w sprawie niektórych warunków produkcji ekologicznej. ${ }^{12}$

Ustawodawstwo unijne regulujące wsparcie rozwoju obszarów wiejskich (w tym wsparcie dla rolnictwa ekologicznego za pomocą płatności rolnośrodowiskowej) skorelowane zostało z kolejnymi okresami budżetowymi Unii. W momencie wejścia Polski do UE (budżet unijny 2000-2006) obowiązywało rozporządzenie Rady (WE) nr 1257/1999 z dnia 17 maja 1999 r. w sprawie wsparcia rozwoju wsi przez Europejski Fundusz Orientacji i Gwarancji Rolnej (EFOiGR), nowelizujące i uchylające niektóre rozporządzenia. ${ }^{13} \mathrm{~W}$ ustawodawstwie krajowym obowiązywała wówczas ustawa z dnia 28 listopada 2003 r. o wspieraniu rozwoju obszarów wiejskich ze środków pochodzących z Sekcji Gwarancji Europejskiego Funduszu Orientacji i Gwarancji Rolnej ${ }^{14}$ oraz wykonawcze rozporządzenie Rady Ministrów z dnia 20 lipca 2004 r. w sprawie szczegółowych warunków i trybu udzielania pomocy finansowej na wspieranie przedsięwzięć rolnośrodowiskowych i poprawy dobrostanu zwierząt objętej planem rozwoju obszarów wiejskich. ${ }^{15}$

W okresie budżetu w latach 2007-2013 płatności rolnośrodowiskowe objęte były „Programem Rozwoju Obszarów Wiejskich na lata 2007-2013”, a podstawowym aktem prawa unijnego było rozporządzenie Rady (WE) nr 1698/2005 z dnia 20 września 2005 r. w sprawie wsparcia rozwoju obszarów wiejskich przez Europejski Fundusz Rolny na rzecz Rozwoju Obszarów Wiejskich. ${ }^{16}$ Ustawodawstwo krajowe stanowiła, często nowelizowana, ustawa z dnia 7 marca 2007 r. o wspieraniu rozwoju obszarów wiejskich z udziałem środków z Europejskiego Funduszu Rozwoju Rolnego na rzecz Rozwoju Obszarów Wiejskich. ${ }^{17}$

Stosowana w omawianym okresie (2007-2013) technika legislacyjna polegała na tym, iż akty wykonawcze do ustawy nie przybierały formy rozporządzenia rządowego, lecz były rozporządzeniem wykonawczym właściwego ministra resortowego. Przyjęto bowiem zasadę, iż każde działanie wspierane w ramach programu rozwoju obszarów wiejskich, w tym „Program rolnośrodowiskowy”, było przedmiotem regulacji odrębnego rozporządzenia wykonawczego ministra. W przypadku programu rolnośrodowiskowego były to, kolejno, rozporządzenia Ministra i Rozwoju Wsi: 1) z dnia 28 lutego 2008 r. w sprawie szczegółowych warunków i trybu przyznawania pomocy finansowej w ramach działania „Program rolnośrodowiskowy” objętego Programem Rozwoju Obszarów Wiejskich na lata 2007-2013, ${ }^{18}$ 2) z dnia 26 lutego

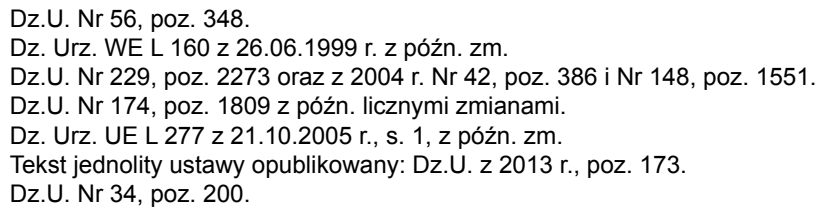


2009 r. ${ }^{19}$ oraz 3) z dnia 13 marca 2013 r. ${ }^{20}$ (kolejne rozporządzenia wykonawcze noszą ten sam tytul). Odnotować należy, iż kolejne rozporządzenia wykonawcze ministra uchylały poprzednio obowiązujące i regulowały te same zagadnienia w sposób bardziej obszerny, szczegółowy, a wręcz kazuistyczny. Dość powiedzieć, że pierwsze z rozporządzeń liczyło 33 paragrafy, drugie - 45, a trzecie już 59 paragrafów, co jest dowodem radosnej twórczości legislacyjnej resortu rolnictwa. Głębsza ocena poziomu legislacji przeprowadzona zostanie $\mathrm{w}$ dalszej części opracowania.

W dniu 20 grudnia 2013 r. opublikowany został Dziennik Urzędowy Unii Europejskiej, w którym zamieszczono m.in. rozporządzenia Parlamentu Europejskiego i Rady (UE):

1) $\mathrm{nr}$ 1305/2013 z 17 grudnia 2013 r. w sprawie wsparcia rozwoju obszarów wiejskich przez Europejski Fundusz Rolny na rzecz Rozwoju Obszarów Wiejskich (EFRROW) i uchylające rozporządzenie Rady (WE) nr 1698/2005;

2) nr 1306/2013 z dnia 17 grudnia 2013 r. w sprawie finansowania i wspólnej polityki rolnej, zarządzania nią i monitorowania jej oraz uchylające rozporządzenia Rady (EWG) nr 352/78, (WE) nr 165/94, (WE) nr 2799/98, (WE) 814/2000, (WE) nr 1290/2005 i (WE) nr 485/2008;

3) nr 1307/2013 z dnia 17 grudnia 2013 r. ustanawiające przepisy dotyczące płatności bezpośrednich dla rolników na podstawie systemów wsparcia w ramach wspólnej polityki rolnej oraz uchylające rozporządzenie Rady (WE) nr 637/2008 i rozporządzenie Rady (WE) nr 73/2009.

Powołane akty normatywne określiły ramy organizacyjno-prawne świadczeń dla rolnictwa w latach 2014-2020, w tym także dla wsparcia rolnictwa ekologicznego. Weszły w życie z dniem opublikowania (20.12.2013 r.), a stosuje się je od dnia 1 stycznia 2014 r. Z tym, że uchylone rozporządzenia stosuje się nadal do operacji realizowanych zgodnie z programami zatwierdzonymi przez Komisję przed dniem 1 stycznia $2014 \mathrm{r}$.

Powyższe rozważania dotyczące dwu nurtów ustawodawstwa regulującego produkcję ekologiczną w rolnictwie mają charakter czysto porządkujący. Były one jednak - zdaniem moim - potrzebne i przydatne, aby, w sytuacji przeplatającego się ustawodawstwa unijnego i krajowego, wzajemnych odwołań, w prawie unijnym także odesłań do aktów normatywnych, które formalnie utraciły mocy (a także odesłań do różnych aktów normatywnych nie zawsze ze sobą spójnych), zwrócić uwagę 
na zasadnicze punkty rozstrzygające o obowiązywaniu przepisów w rzeczywiście skomplikowanym stanie prawnym. ${ }^{21}$

4. Aktualnie obowiązujący, normatywny model organizacyjno-prawny rolnictwa ekologicznego regulowany jest przepisami rozporządzenia Rady nr 834/2007 w sprawie produkcji ekologicznej i znakowania produktów ekologicznych oraz ustawy z dnia 25 czerwca 2009 r. o rolnictwie ekologicznym. W preambule do rozporządzenia Rady znajduje się zapis, że celem wspólnotowych ram prawnych regulujących sektor produkcji ekologicznej powinno być zapewnienie uczciwej konkurencji i właściwego funkcjonowania rynku wewnętrznego produktów ekologicznych, a także uzasadnienie zaufania konsumentów w stosunku do produktów oznaczonych jako ekologiczne.

Rozporządzenie unijne wykracza poza zakres produkcji rolniczej, obejmując wszystkie etapy produkcji, przygotowania i dystrybucji produktów rolnictwa ekologicznego oraz ich kontroli (art. 1 ust. 1 lit. ,a” rozporządzenia). Zgodnie ze słowniczkiem rozporządzenia ,etapy produkcji, przygotowania i dystrybucji” oznaczają każdy etap, począwszy od produkcji wstępnej produktu ekologicznego aż do przechowywania, przetwarzania, transportu, sprzedaży lub zaopatrzenia ostatecznego konsumenta. W konsekwencji rozporządzenie nr 834/2007 stosuje się do następujących produktów pochodzenia rolnego wprowadzonych na rynek lub takich, które mają być wprowadzone na rynek:

a) żywe lub nieprzetworzone produkty rolne;

b) przetworzone produkty rolne przeznaczone do spożycia;

c) pasze;

d) wegetatywny materiał rozmnożeniowy i nasiona do celów uprawy (art. 1 ust. 2 rozporządzenia).

Z przytoczonych uregulowań rozporządzenia nr 834/2007 wynika jednoznacznie, iż celem regulacji jest wprowadzenie na rynek żywnościowy i funkcjonowanie na tym rynku certyfikowanego, ekologicznego produktu rolniczego. Szeroki zakres regulacji wykracza poza ujęte tematem opracowania zagadnienia ,produkcji ekologicznej w rolnictwie”. Stąd w rozważaniach pominięte zostaną wszystkie inne etapy przygotowania i dystrybucji produktów rolnictwa ekologicznego, poza etapem podstawowym - etapem produkcji rolnej. Takie ujęcie potrzebne jest dla ukazania relacji pomiędzy dwoma ww. nurtami regulacji co do produkcji ekologicznej.

Ekologiczna produkcja rolnicza jest koniecznym warunkiem ubiegania się o uzyskanie statusu certyfikowanego produktu ekologicznego, ale także stanowi wa- 
runek uzyskania wsparcia, udzielanego w ramach programów rozwoju obszarów wiejskich, dla działania określonego jak „rolnictwo ekologiczne”. Regulacje dotyczące wsparcia rolnictwa ekologicznego w ramach PROW odsyłają bowiem do rozporządzenia 834/2007.

Cechą charakterystyczną ustawodawstwa unijnego jest rozbudowany, „wielopiętrowy" schemat regulacji z zastosowaniem metody kolejnych przybliżeń. W przypadku ekologicznej produkcji rolniczej reguły określone są poprzez unormowanie:

1) ogólnych celów produkcji ekologicznej,

2) zasad ogólnych, na których jest oparta taka produkcja,

3) szczegółowych zasad dotyczących rolnictwa,

4) ogólnych zasad produkcji rolnej,

5) zasad produkcji roślinnej,

6) zasad produkcji zwierzęcej.

Wymagania w zakresie „ekologiczności” na poszczególnych poziomach regulacji prawnej są oczywiście zróżnicowane, od najbardziej ogólnych do aż nadmiernie kazuistycznych. I tak do ogólnych celów produkcji ekologicznej (pkt 1) należą:

a) stworzenie zrównoważonego systemu zarządzania rolnictwem, który:

(i) uwzględnia system i cykle przyrody oraz utrzymuje i poprawia zdrowotność gleby, wody, roślin i zwierząt oraz równowagę między nimi;

(ii) przyczynia się do utrzymania wysokiego poziomu różnorodności biologicznej;

(iii) korzysta w odpowiedzialny sposób z energii i zasobów naturalnych;

(iv) przestrzega wysokich standardów dotyczących dobrostanu zwierząt;

b) dążenie do wytworzenia produktów wysokiej jakości;

c) dążenie do produkowania szerokiej gamy produktów spożywczych i innych produktów rolnych zaspokajających zapotrzebowanie klientów na towary produkowane przy wykorzystywaniu procesów niestanowiących zagrożenia dla środowiska, zdrowia ludzi, zdrowotności roślin ani dla zdrowia i dobrostanu zwierząt (art. 3 rozporządzenia nr 834/2007).

Spośród zasad ogólnych, na których, według ustawodawcy unijnego, opiera się produkcja ekologiczna wymienić należy:

a) odpowiednie zaprojektowanie procesów biologicznych i zarządzanie nimi, które opiera się na systemach ekologicznych wykorzystujące zasoby naturalne przy zastosowaniu metod, które m.in. wykluczają stosowanie GMO i produktów wytwarzanych z GMO lub przy ich użyciu; 
b) ograniczenie stosowania środków wewnętrznych;

c) ścisłe ograniczenie stosowania środków z syntezy chemicznej do wyjątkowych przypadków;

d) dostosowanie w razie potrzeby, w ramach niniejszego rozporządzenia, zasad produkcji ekologicznej do stanu sanitarnego, regularnych różnic klimatycznych i warunków lokalnych, stopnia rozwoju i szczególnych praktyk gospodarskich (art. 4 rozporządzenia nr 834/2007).

Kolejny poziom wymagań określony jest terminem „szczegółowych zasad dotyczących rolnictwa" uregulowanych przepisem art. 5 rozporządzenia nr 834/2007. Wśród tych zasad (katalog tych zasad oznaczony jest literami od „a” do „o”) wskazać należy przykładowo na następujące:

a) utrzymanie i poprawa życia w glebie i naturalnej żyzności gleby, stabilności i różnorodności biologicznej, zapobieganie i zwalczanie erozji gleby oraz odżywianie roślin głównie poprzez ekosystem gleby;

b) ograniczenie do minimum stosowania zasobów nieodnawialnych oraz środków zewnętrznych;

g) praktykowanie produkcji zwierzęcej powiązanej z powierzchnią gruntów rolnych;

k) żywienie zwierząt paszami ekologicznymi złożonymi ze składników rolniczych uzyskanych $\mathrm{w}$ produkcji ekologicznej oraz $\mathrm{z}$ naturalnych substancji nierolniczych;

1) stosowanie praktyk gospodarskich, które wzmacniają układ odpornościowy i naturalny system obrony przed chorobami, w tym zwłaszcza zapewnienie regularnego ruchu oraz - w miarę możliwości - dostępu do terenów na wolnym powietrzu i pastwisk (art. 5 rozporządzenia).

Na czwartym poziomie szczegółowości docieramy do ogólnych zasad produkcji rolnej, które wyrażają się w jednym zdaniu: całe gospodarstwo rolne jest zarządzane zgodnie z wymogami mającymi zastosowanie do produkcji ekologicznej. Jeżeli nie wszystkie jednostki gospodarstwa są wykorzystywane do produkcji ekologicznej, podmiot gospodarczy oddziela ziemię, zwierzęta i produkty używane do produkcji ekologicznej, od tych wykorzystywanych do produkcji nieekologicznej, prowadząc odpowiednią dokumentację potwierdzającą podział (art. 11 rozporządzenia nr 834/2007).

Dalsze wymagania odnośnie produkcji rolniczej ustanowione zostały z wyodrębnieniem zasad produkcji roślinnej oraz zasad produkcji zwierzęcej. Do ekologicznej produkcji roślinnej stosuje się m.in. zasady następujące: 
1) w ekologicznej produkcji roślinnej stosuje się praktyki uprawy, które przyczyniają się do utrzymania lub zwiększenia ilości substancji organicznych w glebie, zwiększają jej stabilność i różnorodność biologiczną oraz zapobiegają zagęszczaniu i erozji gleby;

2) żyzność i aktywność biologiczna gleby jest utrzymywana i zwiększana poprzez stosowanie wieloletniego płodozmianu;

3) nie stosuje się mineralnych nawozów azotowych;

4) wszelkie stosowane techniki produkcji roślinnej zapobiegają zanieczyszczaniu środowiska lub ograniczają je do minimum;

5) zapobieganie szkodom wyrządzanym przez szkodniki, choroby i chwasty polega przede wszystkim na ochronie ich naturalnych wrogów, doborze gatunków i odmian, stosowaniu płodozmianu, odpowiednich technik uprawy i zabiegów termicznych (art. 12 ust. 1 lit. ,a - 1” rozporządzenia nr 834/2007).

W sposób szczególnie drobiazgowy sformułowane zostały zasady (wymogi) dotyczące produkcji zwierzęcej. W artykule 14 rozporządzenia nr 834/2007 wymieniono blisko 30 wymogów: w odniesieniu do pochodzenia zwierząt (zwierzęta ekologiczne są urodzone i chowane w gospodarstwach ekologicznych); w odniesieniu do praktyk gospodarskich i warunków w pomieszczeniach dla zwierząt (trzymanie zwierząt na uwięzi i ich izolowanie jest zabronione, aczkolwiek z wyjątkami); w odniesieniu do hodowli (stosuje się naturalne metody reprodukcji, dozwolone jest sztuczne zapłodnienie, ale nie stosuje się klonowania i przenoszenia zarodków); w odniesieniu do pasz (pasze dla zwierząt pozyskuje się przede wszystkim z gospodarstwa, w którym zwierzęta są utrzymywane lub z innych gospodarstw ekologicznych; zwierzęta mają stały dostęp do pastwisk lub pasz objętościowych); $\mathrm{w}$ odniesieniu do zapobiegania chorobom i leczenia weterynaryjnego, a także co do czyszczenia i odkażania pomieszczeń zwierząt.

Przytoczone powyżej cele i zasady ogólne rolnictwa ekologicznego, zasady produkcji rolnej, w tym roślinnej i zwierzęcej, sformułowane zostały w różnym stopniu kategoryczności, przy użyciu zarówno ogólnikowych klauzul mających charakter niedookreślony, jak i wymagań ustalonych bardzo kazuistycznie, co jest swoistą manierą unijnej techniki legislacyjnej. Uzupełniające ustawodawstwo krajowe obowiązujące w tym przedmiocie wcale nie ułatwia stosowania prawa. Zgodnie z przepisem art. 4 ust. 6 obowiązującej ustawy o rolnictwie ekologicznym, w wykazie producentów ekologicznych mogą się znaleźć tacy, którzy: dokonali zgłoszenia podjęcia działalności w zakresie rolnictwa ekologicznego, o którym mowa w art. 28 ust. 1 rozporządzenia $\mathrm{nr}$ 834/2007 i spełnili określone w przepisach dotyczących rolnictwa ekologicznego warunki do prowadzenia tej działalności. A przepisami dotyczącymi rolnictwa ekologicznego są - zgodnie ze słowniczkiem zamieszczonym w art. 2 pkt 5 ustawy - przepisy rozporządzenia nr 834/2007 i przepisy Unii Europej- 
skiej wydane w trybie przepisów tego rozporządzenia oraz przepisy ustawy i aktów wykonawczych do ustawy. ${ }^{22}$ Poruszanie się w takim gąszczu przepisów, stawiających bardzo różnorodne wymogi czy warunki pragnącym uzyskać status producenta ekologicznego, wymaga dobrej znajomości zasad stosowania prawa unijnego. Osobiście jestem zdania, iż w unijnej regulacji rolnictwa ekologicznego w miejsce operowania różnorodnymi terminami z przymiotnikiem ,ekologiczny /-a/" przydatne byłoby zdefiniowanie ,gospodarstwa ekologicznego” ze wskazaniem na istotne, acz w miarę ogólne elementy konstrukcyjne. Nie jest to zadanie proste, lecz wykonalne. Poziom legislacji determinuje poziom stosowania prawa.

Aktualnie ciężar stosowania przepisów o rolnictwie ekologicznym spoczywa na jednostkach certyfikujących oraz organach inspekcji rządowych, sprawujących nadzór nad jednostkami certyfikującymi oraz nadzór nad produkcją ekologiczną.

Przepisy ustawy (art. 5 i 6) przewidują specjalną procedurę administracyjną regulującą tryb uzyskania statusu jednostki certyfikującej. Podmiot ubiegający się o upoważnienie do działania jako jednostka certyfikująca składa wniosek do ministra właściwego do spraw rolnictwa, określając zakres wnioskowanego upoważnienia, dołączając wymagane informacje, dokumenty i opinie. Minister, w drodze decyzji, upoważnia do działania w charakterze jednostki certyfikującej; w podobnym trybie dokonuje się zmiany upoważnienia, a także, w przypadkach określonych przepisami rolnictwa ekologicznego, cofnięcia upoważnienia. Do postępowania w sprawach indywidualnych, rozstrzyganych w drodze decyzji, stosuje się przepisy Kodeksu postępowania administracyjnego.

Na stronie internetowej Ministra Rolnictwa i Rozwoju Wsi (wykazującej stan na 22.08.2013 r.) opublikowany jest „Rejestr jednostek certyfikacyjnych w rolnictwie ekologicznym w Polsce", w którym zamieszczono wykaz 9 jednostek certyfikujących, posiadających status spółek akcyjnych lub spółek z ograniczoną odpowiedzialnością. ${ }^{23}$ Wszystkie zarejestrowane jednostki certyfikujące posiadają upoważnienie do przeprowadzania kontroli oraz wydawania i cofania certyfikatów zgodności w rolnictwie ekologicznym w zakresie: Ekologiczna uprawa roślin i utrzymywanie zwierząt.

Zgodnie z art. 28 rozporządzenia nr 834/2007, każdy podmiot gospodarczy podejmujący działalność gospodarczą w zakresie rolnictwa ekologicznego:

a) zgłasza tę działalność właściwym organom państwa członkowskiego, w którym działalność ta jest wykonywana,

Przykładem wykonawczego rozporządzenia do ustawy jest rozporządzenie Ministra Rolnictwa i Rozwoju Wsi z dnia 18 marca 2010 r. w sprawie niektórych warunków produkcji ekologicznej (Dz.U. Nr 56, poz. 348). Wydane na podstawie art. 19 ust. 1 ustawy rozporządzenie reguluje nieliczne odstępstwa od ogólnych rozwiązań unijnych. Samo rozporządzenie może stanowić doskonały wzorzec nadmiernej i zbędnej kazuistyki w legislacji. W wykazie znajduje się m.in. Polskie Centrum Badań i Certyfikacji S.A. w Warszawie, Biocert Małopolska sp. z o.o. w Krakowie, Agro Bio Test sp. z o.o. w Warszawie. 
b) przekazuje zgodę na objęcie jego działań systemem kontroli, o którym mowa $\mathrm{w}$ art. 27 rozporządzenia.

W naszym systemie organizacyjnym to jednostki certyfikujące:

1) przyjmują zgłoszenia podjęcia działalności w zakresie rolnictwa ekologicznego,

2) prowadzą kontrolę, na zasadach i w sposób określony na podstawie art. 27 rozporządzenia nr 834/2007 i w przepisach wydanych na podstawie tego artykułu (art. 7 ustawy),

3) sporządzają wykazy producentów, którzy dokonali zgłoszenia i spełnili określone w przepisach rolnictwa ekologicznego warunki do prowadzenia tej działalności,

4) wydają każdemu podmiotowi (który podlega ich kontroli i który spełnia ww. warunki) certyfikat; certyfikat winien umożliwiać co najmniej identyfikację podmiotu oraz rodzaju lub asortymentu produktów, a także okres ważności,

5) odmawiają wydania certyfikatu.

Wpis do wykazu producentów ekologicznych oraz wydanie certyfikatu, który jest sui generis zaświadczeniem zaliczyć należy do czynności materialno-technicznych, natomiast odmowa wydania certyfikatu ma charakter decyzji administracyjnej, od której - zdaniem moim - służy odwołanie do organu wyższego stopnia. Ponieważ decyzja administracyjna (o odmowie wydania certyfikatu) wydawana jest przez ,inny podmiot powołany z mocy prawa" (w rozumieniu art. 1 pkt 2 k.p.a.) do załatwiania spraw indywidualnych $\mathrm{w}$ drodze decyzji, to organem wyższego stopnia, w rozumieniu art. 17 k.p.a., mogą być organy państwowe sprawujące nadzór nad działalnością takich podmiotów. Zgodnie z art. 8 ust. 1 ustawy o rolnictwie ekologicznym, nadzór nad jednostkami certyfikującymi sprawuje ,inspekcja”. Chodzi tu o Inspekcję Jakości Handlowej Artykułów Rolno-Spożywczych, będącą inspekcją działającą w ramach administracji rządowej, podlegającą ministrowi właściwemu do spraw rynków rolnych, funkcjonującą na podstawie ustawy z dnia 21 grudnia 2000 r. o jakości handlowej artykułów rolno-spożywczych ${ }^{24}$ oraz przepisów wykonawczych do tej ustawy. ${ }^{25} \mathrm{~W}$ skład omawianej inspekcji wchodzą: 1) Główny Inspektor Jakości Handlowej Artykułów Rolno-Spożywczych oraz 2) inspektorzy wojewódzcy. Główny Inspektor może powierzyć sprawowanie nadzoru inspektorowi wojewódzkiemu, właściwemu miejscowo. Wówczas wojewódzki inspektor będzie pełnił funkcję organu odwoławczego w przypadku odwołań od decyzji odmawiającej wydania certyfikatu. 
Organy i funkcjonariuszy inspekcji rządowych odróżnić należy od osób posiadających uprawnienia ,inspektora rolnictwa ekologicznego”. Osoby takie mogą prowadzić kontrolę na zlecenie jednostek certyfikujących, na podstawie i w trybie określonym w art. 7 ustawy o rolnictwie ekologicznym. Inspektorzy rolnictwa ekologicznego, zgodnie z art. 21 ustawy, to osoby upoważnione do prowadzenia kontroli, o której mowa w art. 7 ustawy, na podstawie wpisu do rejestru prowadzonego przez Głównego Inspektora Jakości Handlowej Artykułów Rolno-Spożywczych. Do rejestru inspektorów rolnictwa ekologicznego może być wpisana osoba, która posiada wiedzę techniczną i praktyczną niezbędną do prowadzenia kontroli, o której mowa w art. 7 ustawy, potwierdzoną egzaminem zdanym przed komisją kwalifikacyjną powołaną przez Głównego Inspektora. ${ }^{26}$ Jeszcze raz podkreślić należy, że inspektorzy rolnictwa ekologicznego są uprawnieni, na zlecenie jednostek certyfikujących, do prowadzenia kontroli producentów ekologicznych, a nie do sprawowania nadzoru.

Nadzór nad jednostkami certyfikującymi oraz nadzór nad produkcją ekologiczną sprawowany jest przez Inspekcję Jakości Handlowej Artykułów Rolno-Spożywczych. Nad jednostkami certyfikującymi nadzór jest sprawowany na zasadach i w sposób określony na podstawia art. 27 rozporządzenia nr 834/2007 i przepisów wydanych na podstawie tego przepisu oraz przepisów o jakości handlowej artykułów rolno-spożywczych dotyczących postępowania kontrolnego; na podstawie przepisów o jakości handlowej artykułów rolno-spożywczych sprawowany jest nadzór nad produkcją ekologiczną (art. 8 ustawy). W realizacji funkcji nadzoru z Inspekcją Jakości Handlowej ustawowy obowiązek współpracy mają inne inspekcje państwowe, a mianowicie: Inspekcja Handlowa, Inspekcja Weterynaryjna oraz Państwowa Inspekcja Ochrony Roślin i Nasiennictwa (art. 14-16 ustawy).

$\mathrm{Na}$ jednostkach certyfikujących, przyjmujących zgłoszenia i dokonujących kontroli w produkcji ekologicznej, ciąży szereg obowiązków sprawozdawczo-informacyjnych. I tak, jednostka certyfikująca przekazuje:

1) Głównemu Inspektorowi Jakości Handlowej, do 10 dnia każdego miesiąca, wykaz producentów ekologicznych, którzy dokonali zgłoszenia podjęcia działalności w zakresie rolnictwa ekologicznego i spełnili warunki dotyczące prowadzenia tej działalności (art. 4 ust. 6 ustawy);

2) Głównemu Inspektorowi, do dnia 31 stycznia każdego roku - wykaz, a do dnia 31 marca każdego roku - sprawozdanie, o których mowa w art. 27 ust. 14 rozporządzenia nr 834/2007, które zawierają dane i informacje zebrane przez tę jednostkę, wynikające z posiadania przez nią zakresu upoważnienia do działania w rolnictwie ekologicznym; 
3) ministrowi właściwemu do spraw rolnictwa oraz Prezesowi Agencji Restrukturyzacji i Modernizacji Rolnictwa, w formie papierowej i elektronicznej; do dnia 31 października każdego roku, wykaz producentów w rozumieniu przepisów o krajowym systemie ewidencji producentów, ewidencji gospodarstw rolnych oraz ewidencji wniosków o przyznanie płatności, którzy spełnili określone wymagania dotyczące produkcji ekologicznej zgodnie z przepisami dotyczącymi rolnictwa ekologicznego, według stanu za ten rok (art. 17 ust. 1 pkt 1 i 2 ustawy).

Wykaz, o którym mowa w pkt. 3, stanowi dokument urzędowy w rozumieniu przepisów k.p.a. dla celów postępowania dowodowego w postępowaniu prowadzonym w sprawach związanych $\mathrm{z}$ udzielaniem pomocy finansowej producentom ekologicznym, na podstawie przepisów o wspieraniu rozwoju obszarów wiejskich ze środków pochodzących z Sekcji Gwarancji Europejskiego Funduszu Orientacji i Gwarancji Rolnej oraz przepisów o wspieraniu rozwoju obszarów wiejskich z udziałem środków Europejskiego Funduszu Rolnego na rzecz Rozwoju Obszarów Wiejskich (art. 17 ust. 3 ustawy).

W ten oto sposób docieramy do drugiego nurtu ustawodawstwa, w którym „Rolnictwo ekologiczne” jest jednym z pakietów w ramach działania „Program rolnośrodowiskowy”, służącego wsparciu rozwoju obszarów wiejskich.

5. Znalezienie się w wykazie producentów ekologicznych jest tylko dowodem spełnienia jednego z warunków uzyskania płatności rolnośrodowiskowej. Warunki uzyskania płatności rolnośrodowiskowej określane są systemem przepisów regulujących wsparcie rozwoju obszarów wiejskich. W latach 2007-2013 były to przepisy unijnego rozporządzenia Rady nr 1698/2005, ustawy z dnia 7 marca 2007 r. oraz trzech, kolejno następujących po sobie, rozporządzeń wykonawczych Ministra Rolnictwa w sprawie szczegółowych warunków przyznawania płatności rolnośrodowiskowych (przepisy te zostały precyzyjnie powołane w akapicie 3. wraz z podaniem miejsca ich publikacji w odsyłaczach 15-19).

Wprawdzie Program Rozwoju Obszarów Wiejskich (2007-2013) został już zrealizowany i rozporządzenie $\mathrm{nr}$ 1698/2005 formalnie utraciło moc, jednakże rozporządzenie to stosuje się nadal do operacji realizowanych zgodnie z programami zatwierdzonymi przez Komisję Europejską na mocy tego rozporządzenia przed dniem 1 stycznia 2014 r., ${ }^{27}$ dlatego też warto przedstawić podstawowe rozwiązania konstrukcyjne modelu organizacyjno-prawnego przyznawania płatności rolnośrodowiskowych. 
Rozwiązania te przedstawiały się następująco:

1) płatności rolnośrodowiskowe należą do środków wsparcia ukierunkowanych na zrównoważone użytkowanie gruntów rolnych (oś 2 - Poprawa środowiska naturalnego i terenów wiejskich);

2) płatności udziela się rolnikom, którzy dobrowolnie podejmują zobowiązania rolnośrodowiskowe; innym osobom gospodarującym gruntami - w przypadkach uzasadnionych do osiągania celów związanych ze środowiskiem naturalnym;

3) płatności rolnośrodowiskowe obejmują jedynie te zobowiązania, które wykraczają poza odpowiednie normy i wymogi w zakresie zarządzania oraz dobrej kultury rolnej zgodnie z ochroną środowiska, ustanowione dla rolników przepisami unijnymi regulującymi systemy wsparcia bezpośredniego;

4) beneficjent otrzymujący płatności rolnośrodowiskowe przestrzega w całym gospodarstwie podstawowych wymogów w zakresie zarządzania oraz zasad dobrej kultury rolnej zgodnej z ochroną środowiska, także w sytuacji, gdy płatność rolnośrodowiskową otrzymuje odnośnie części gospodarstwa;

5) zobowiązania rolnośrodowiskowe podpisywane są z reguły na okres od pięciu do siedmiu lat; płatności udziela się corocznie i obejmują one dodatkowe koszty i utracone dochody wynikające z podjętego zobowiązania (art. 36, 39 i 50 ,a” rozporządzenia $\mathrm{nr}$ 1698/2005).

Regulacja z dnia 7 marca 2007 r. o wspieraniu rozwoju obszarów wiejskich w zakresie płatności rolnośrodowiskowych nie jest obszerna. Ustawa zalicza płatności do jednego z rodzajów działań wspierających rozwój obszarów wiejskich używając określenia „program rolnośrodowiskowy” (art. 5 ust. 1 pkt 14 ustawy). Pomoc w ramach działania, o którym mowa w art. 5 ust. 1 pkt 14, jest przyznawana w drodze decyzji administracyjnej, a organem właściwym do podjęcia decyzji jest kierownik biura powiatowego Agencji Restrukturyzacji i Modernizacji Rolnictwa (art. 20 ust. 1 i 2 ustawy). Do postępowania administracyjnego poprzedzającego wydanie decyzji mają zastosowanie przepisy k.p.a. zmodyfikowane przepisem art. 21 ustawy z 7 marca 2007 r. o wspieraniu rozwoju obszarów wiejskich. ${ }^{28}$ Ustawa udzieliła Ministrowi Rolnictwa i Rozwoju Wsi szerokich upoważnień do wydania rozporządzenia wykonawczego (art. 29 ustawy), co jest zgodne z art. 39 ust. 1 rozporządzenia Rady nr 1698/2005 upoważniającym państwa członkowskie do udostępnienia wsparcia ,płatnością rolnośrodowiskową” zgodnie ze swoimi szczególnymi potrzebami. 
Na szczeblu rozporządzenia wykonawczego Ministra Rolnictwa i Rozwoju Wsi ${ }^{29}$ jednolite działanie „Program rolnośrodowiskowy” doznaje konkretyzacji. Zgodnie z $\$ 4$ rozporządzenia zobowiązanie rolnośrodowiskowe jest realizowane w ramach co najmniej jednego z dziewięciu pakietów. Rolnictwo ekologiczne jest jednym z nich, oznaczonym jako „Pakiet $2 ” .{ }^{30}$ Co więcej, zobowiązanie rolnośrodowiskowe w ramach poszczególnych pakietów może być jeszcze różnicowane w postaci wariantów. W ramach pakietu ,rolnictwo ekologiczne” wyróżnia się osiem wariantów. ${ }^{31}$ Trzypiętrowa regulacja szczególnych warunków przyznawania pomocy jest - zdaniem moim - przejawem przeregulowania, zbyt drobiazgowych prób regulowania zjawisk gospodarczych, które powinny być stymulowane w sposób elastyczny.

W konsekwencji przyjętej techniki legislacyjnej w rozporządzeniu wykonawczym należy wyróżnić trzy progi wymagań, gdy chodzi o uzyskanie płatności rolnośrodowiskowej w ramach konkretnego wariantu rolnictwa ekologicznego.

Pierwszy próg dotyczy wszystkich rolników ubiegających się o płatność rolnośrodowiskową, niezależnie od pakietu. I tak, płatność rolnośrodowiskową przyznaje się:

1) rolnikowi w rozumieniu art. 2 lit. ,,a” rozporządzenia Rady nr 73/2009,23 któremu został nadany numer identyfikacyjny w trybie przepisów o krajowym systemie ewidencji producentów, ewidencji gospodarstw rolnych oraz ewidencji wniosków o przyznanie płatności, który jest posiadaczem działek rolnych o łącznej powierzchni co najmniej 1 ha;

2) rolnikowi, który realizuje 5-letnie zobowiązanie rolnośrodowiskowe, o którym mowa w art. 39 rozporządzenia nr 1698/2005; zobowiązanie winno

Obowiązujące rozporządzenie Ministra Rolnictwa i Rozwoju Wsi wydane zostało w dniu 13 marca 2013 r. (Dz.U. 2013, poz. 361). Zaznaczyć należy, iż „Program rolnośrodowiskowy” był jedynym działaniem w naszym prawodawstwie, dla którego, w latach 2007-2013, zostały wydane 3 kolejne rozporządzenia wykonawcze ministra, a mianowicie: 1) rozporządzenie z dnia 28 lutego 2008 r. (Dz.U. Nr 34, poz. 200), 2) rozporządzenie z dnia 26 lutego 2009 r. (Dz.U. Nr 33, poz. 262 ze zm.) i 3) aktualnie obowiązujące rozporządzenie z 13 marca 2013 r. wydane w ostatnim roku Programu Rozwoju Obszarów Wiejskich na lata 2007-2013. Trudno mówić o stabilności rozwiązań prawnych.

30 Oprócz pakietu 2: Rolnictwo ekologiczne, były to pakiety następujące: pakiet 1. Rolnictwo zrównoważone; pakiet 3. Ekstensywne trwałe użytki zielone; pakiet 4. Ochrona zagrożonych gatunków ptaków i siedlisk przyrodniczych poza obszarami Natura 2000; pakiet 5. Ochrona zagrożonych gatunków ptaków i siedlisk przyrodniczych na obszarach Natura 2000; pakiet 6 . Zachowanie zagrożonych zasobów genetycznych roślin w rolnictwie; pakiet 7. Zachowanie zagrożonych zasobów genetycznych zwierząt w rolnictwie; pakiet 8 . Ochrona gleb i wód; pakiet 9. Strefy buforowe.

31 Zgodnie z załącznikami 3 i 4 do rozporządzenia w ramach rolnictwa ekologicznego - pakiet 2 wyodrębnia się warianty: wariant 2.1. - uprawy rolnicze (dla których zakończono okres przestawiania) i wariant 2.2. - uprawy rolnicze (w okresie przestawiania). W pozostałych wariantach też mamy do czynienia z podziałem danej kategorii wariantu na ten, gdzie zakończono konwersję (przestawianie) produkcji konwencjonalnej na specjalistyczną i na ten, gdzie produkcja znajduje się w okresie przestawiania. Dalsze warianty to: 2.3. i 2.4. - trwałe użytki zielone (w obu wersjach), 2.5. i 2.6. - uprawy warzywne (w obu wersjach), 2.7. i 2.8. - uprawy zielarskie (w obu wersjach).

32 Rozporządzenie Rady (WE) nr 73/2009 z dnia 19 styczna 2009 r. ustanawiające wspólne zasady dla systemów wsparcia bezpośredniego dla rolników w ramach wspólnej polityki rolnej (Dz. Urz. UE L 30 z 31.01.2009 r.). 
obejmować wymogi wykraczające ponad podstawowe wymagania, w ramach określonych pakietów i ich wariantów, zgodnie z planem działalności rolnośrodowiskowej.

Podstawowymi wymaganiami, o których wyżej mowa, są:

1) wymogi i normy określone w przepisach o płatnościach w ramach systemów wsparcia bezpośredniego (rozporządzenie $\mathrm{nr} 73 / 2009$ );

2) minimalne wymogi dotyczące stosowania nawozów i środków ochrony roślin, wymienione w załączniku nr 2 do rozporządzenia nr 1698/2005;

3) inne odpowiednie wymogi obowiązkowe, wymienione w załączniku nr 2 do rozporządzenia $\mathrm{nr}$ 1698/2005.

Kolejne wymagania formułowane są w ramach poszczególnych pakietów, ponieważ przyznawanie płatności rolnośrodowiskowej, wg polskiego prawodawstwa, możliwe jest $w$ ramach określonych pakietów i ich wariantów. Zgodnie z $§ 10$ pkt 2 rozporządzenia wykonawczego ministra, płatność rolnośrodowiskowa w ramach pakietu: „Rolnictwo ekologiczne” jest przyznawana:

a) w ramach wszystkich ośmiu wariantów - jeżeli rolnik prowadzi produkcję rolną zgodnie z przepisami o rolnictwie ekologicznym, przepisami rozporządzenia Rady (WE) nr 834/2007 z dnia 28 czerwca 2007 r. w sprawie produkcji ekologicznej i znakowania produktów ekologicznych i uchylającego rozporządzenie (EWG) nr 2092/91 (Dz. Urz. UE L 189 z 20.07.2007 z późn. $\mathrm{zm}$.) oraz przepisami wydanymi $\mathrm{w}$ trybie przepisów tego rozporządzenia, w szczególności w zakresie uprawy roślin,

b) w ramach wariantu trzeciego i czwartego (dotyczących wykorzystywania trwałych użytków zielonych) - płatność jest przyznawana, jeżeli rolnik w okresie od dnia 15 marca do dnia 30 września roku, w którym złożył wniosek o przyznanie płatności rolnośrodowiskowej, był posiadaczem bydła, koni, owiec lub kóz, co potwierdza wpis lub zgłoszenie tych zwierząt do rejestru zwierząt gospodarskich oznakowanych lub do rejestru koniowatych, o których mowa w przepisach o systemie identyfikacji i rejestracji zwierząt.

Warunek uregulowany w $\S 10$ pkt 2 lit. „,b” jest przykładem nieudanej, zbyt szczegółowej, resortowej regulacji prawnej. Wątpliwości budzi okoliczność, czy warunek określony lit. „b” jest warunkiem dodatkowym w stosunku do wymogu określonego lit. ,a” skoro ten dotyczy „,wszystkich wariantów”, czy jest warunkiem alternatywnym, samoistnym, wystarczającym do uzyskania płatności w ramach wariantu trzeciego i czwartego. Wątpliwości tych nie wyjaśnia, a rodzi nowe, przepis $\S 14$ rozporządzenia ministra określającego precyzyjnie płatność rolnośrodowiskową. Ponieważ treści tego przepisu nie sposób oddać własnymi zdaniami, pozwalam sobie na może zbyt długi cytat: 
„§ 14.1. Płatność rolnośrodowiskowa za realizację wariantu trzeciego i czwartego pakietu wymienionego w $\S 4$ ust. 1 pkt 2 przysługuje do powierzchni działek rolnych użytkowanych jako trwałe użytki zielone zadeklarowanych we wniosku o przyznanie płatności rolnośrodowiskowej w ramach tych wariantów i objętych obszarem zatwierdzonym w rozumieniu art. 6 ust. 2 lit. „c” rozporządzenia nr 65/2011, nie większej jednak niż powierzchnia ustalona jako iloraz liczby zwierząt, o których mowa w $§ 10$ pkt 2 lit. „b”, przeliczonych na duże jednostki przeliczeniowe, i współczynnika 0,5 .

2. W przypadku gdy rolnik realizuje wariant trzeci jednocześnie $\mathrm{z}$ wariantem czwartym pakietu wymienionego w $\S 4$ ust. 1 pkt 2 , a powierzchnia ustalona jako iloraz liczby zwierząt, o których mowa w $§ 10$ pkt 2 lit. „,b”, przeliczonych na duże jednostki przeliczeniowe, i współczynnika 0,5 jest mniejsza od powierzchni dzialek rolnych użytkowanych jako trwałe użytki zielone zadeklarowanych we wniosku o przyznanie płatności rolnośrodowiskowej w ramach wariantu trzeciego i czwartego pakietu wymienionego $\mathrm{w} \S 4$ ust. 1 pkt 2 i objętych obszarem zatwierdzonym w rozumieniu art. 6 ust. 2 lit. „," rozporządzenia nr 65/2011, płatność rolnośrodowiskowa w pierwszej kolejności przysługuje do powierzchni, na której jest realizowany wariant czwarty tego pakietu."

Cytowany przepis ma jeszcze cztery ustępy, ale już przywołane przepisy dają czytelnikowi obraz poziomu techniki legislacji resortowej. Można jedynie stwierdzić, iż jest to przykład przeregulowania zjawisk gospodarczych, prowadzącego jedynie do deprecjacji prawa. Wypada także wyrazić podziw dla pracowników ARiMR, do kompetencji których należy stosowanie tych przepisów.

Poza rolniczą produkcją ekologiczną prowadzoną na trwałych użytkach zielonych (wariant trzy i cztery), pozostałe warianty rolnictwa ekologicznego odnoszą się do działek rolnych użytkowanych jako grunty orne. $\mathrm{Z}$ tym, że - zgodnie z przepisem $\S 12$ ust. 2 pkt 1 rozporządzenia - płatność rolnośrodowiskowa przyznawana jest, jeżeli na działkach tych występują uprawy wymienione w ust. 1 załącznika $\mathrm{nr} 4$ do rozporządzenia. ${ }^{33} \mathrm{~W}$ ustępie tym stwierdza się, że pakiet 2 - „Rolnictwo ekologiczne" obejmuje następujące uprawy. W tym miejscu zamieszczono trzy wykazy upraw (z podaniem nazwy polskiej danej rośliny uprawnej i nazwy łacińskiej gatunku):

1) uprawy rolnicze (wykaz zawiera 131 pozycji);

2) uprawy warzywne (wykaz zawiera 76 pozycji);

3) uprawy zielarskie (wykaz zawierający 54 pozycje).

Papierowa wersja „Dziennika Ustaw” byłaby cieńsza (ochrona lasów), gdyby wykazy skonstruowane były w poprawny legislacyjnie sposób. Należy rozpocząć 
od wykazów upraw warzywnych i upraw zielarskich, a na końcu, zamiast wykazu upraw rolniczych (131 pozycji) zamieścić jednopunktową klauzulę zamykającą - ,pozostałe uprawy rolnicze”. Nie udało mi się znaleźć rośliny uprawnej, która nie byłaby zamieszczona w ww. wykazach obejmujących 261 gatunków roślin uprawnych. Zdziwienie jedynie budzi zaliczenie ,ziemniaka”, w warunkach polskich, do upraw warzywnych, a nie upraw rolniczych (za uprawy warzywne przysługują wyższe płatności).

W obszerny i szczegółowy sposób uregulowane zostały procedury przyznawania płatności, kontroli spełniania warunków, a następnie kontroli wypełniania zobowiązania rolnośrodowiskowego, a także stosowania sankcji w przypadku stwierdzenia niezgodności w wykonaniu zobowiązania ( $\$ 23-\S 46$ rozporządzenia). Zdziwienie budzi brak jakichkolwiek reguł dotyczących rolnictwa ekologicznego, gdy chodzi o współdziałanie pomiędzy jednostkami organizacyjnymi ARiMR a inspekcjami nadzorującymi produkcję w rolnictwie ekologicznym.

6. Rozporządzenie Parlamentu Europejskiego i Rady (UE) nr 1305/2013 z dnia 17 grudnia 2013 r. w sprawie wsparcia rozwoju obszarów wiejskich, które stosuje się od dnia 1 stycznia 2014 r.. zapowiada (teza 23 preambuły) i reguluje (przepisy art. 29 oraz 28 ust. 8), na szczeblu unijnym, nowe podejście do rolnictwa ekologicznego jako jednego z działań w ramach wsparcia rozwoju obszarów wiejskich w latach 2014-2020.

Najważniejszym rozstrzygnięciem nowego ustawodawstwa unijnego jest wyodrębnienie (na tym szczeblu decyzyjnym) rolnictwa ekologicznego jako samodzielnego działania, odrębnego od „Działania rolno-środowiskowo-klimatycznego”, regulowanego przepisem art. 28 rozporządzenia. Zgodnie z art. 28 ust. $8 \mathrm{w}$ ramach działania rolno-środowiskowo-klimatycznego nie można udzielać wsparcia na zobowiązania objęte działaniem dotyczącym rolnictwa ekologicznego.

Swoistą nowością jest zapowiedź, aby w celu zwiększenia korzyści płynących z działań w dziedzinie rolnictwa ekologicznego zachęcać do tego, aby zawieranie umów zbiorowych lub współpraca między rolnikami obejmowały większe, przyległe obszary. W celu uniknięcia masowego powrotu rolników do rolnictwa konwencjonalnego należy udzielać wsparcia zarówno dla działań związanych z konwersją na rolnictwo ekologiczne, jak i z utrzymaniem takiego rolnictwa. W celu zapewnienia efektywnego wykorzystania zasobów EFRROW wsparcie powinno ograniczać się do rolników aktywnych zawodowo w rozumieniu art. 9 rozporządzenia (UE) nr $1307 / 2013$ (teza 23. preambuły).

W konsekwencji tych założeń programowych przepis art. 29 rozporządzenia reguluje „Rolnictwo ekologiczne” w sposób następujący: „Wsparcia w ramach tego działania udziela się na hektar użytków rolnych rolnikom lub grupom rolników, którzy dobrowolnie podejmują się konwersji lub utrzymania praktyk i metod rolnictwa 
ekologicznego określonych w rozporządzeniu (WE) nr 834/2007 i którzy są rolnikami aktywnymi zawodowo w rozumieniu art. 9 rozporządzenia (UE) nr 1307/2013." (art. 29 ust. 1).

Pozostałe elementy określające wsparcie dla rolnictwa skonstruowane zostały podobnie jak przy dotychczasowej płatności rolnośrodowiskowej, mianowicie:

1) wsparcia udziela się jedynie w odniesieniu do zobowiązań, które wykraczają poza odpowiednie obowiązkowe normy ustanowione rozmaitymi przepisami unijnymi regulującymi finansowanie wspólnej polityki rolnej;

2) zobowiązania w ramach tego działania podejmowane są na okres od pięciu do siedmiu lat;

3) płatności udziela się corocznie; rekompensują one beneficjentom całość lub część dodatkowych kosztów i dochodów utraconych w wyniku podjętych zobowiązań;

4) wsparcie ogranicza się do wysokości maksymalnych kwot określonych w załączniku II do rozporządzenia (są to kwoty od 450 do 900 euro na hektar w zależności od sposobu użytkowania gruntów) (art. 29 ust. 2-6 rozporządzenia).

Podstawowe rozwiązania konstrukcyjne dotyczące rolnictwa ekologicznego podnoszą niewątpliwie rangę tego rolnictwa i jego pozycję we Wspólnej Polityce Rolnej. Warto w tym miejscu przytoczyć stanowiska organów unijnych wypowiedziane w tezie (22) preambuły do omawianego rozporządzenia: „Państwa członkowskie powinny utrzymać poziom wysiłków podjętych w okresie programowania 2007-2013 i powinny być zobowiązane do wydawania co najmniej 30\% całkowitego wkładu EFRROW na każdy program rozwoju obszarów wiejskich dotyczący kwestii związanych z łagodzeniem zmiany klimatu i przystosowaniem się do niej, a także kwestiami środowiskowymi. Takie wydatki powinny być dokonywane poprzez płatności rolno-środowiskowo-klimatyczne i płatności na rzecz rolnictwa ekologicznego oraz płatności dla obszarów z ograniczeniami naturalnymi lub innymi szczególnymi ograniczeniami, poprzez płatności dla leśnictwa, płatności dla obszarów Natura 2000 oraz wsparcie inwestycji na rzecz środowiska i klimatu.”. Nie ulega wątpliwości, że wsparcie rozwoju rolnictwa ekologicznego nie jest wsparciem dla produkcji produktu ekologicznego i poziomu jego podaży na rynku żywnościowym, lecz służy rekompensacie strat ponoszonych przez producentów rolnych na skutek prowadzenia produkcji rolnej zgodnie ze standardami produkcji ekologicznej, a więc z podwyższonymi wymogami w zakresie ochrony i poszanowania środowiska.

Czy nowa regulacja prawna w zakresie płatności na rzecz rolnictwa ekologicznego będzie kolejnym „kamieniem milowym” w jego rozwoju? Zależeć to będzie 
od poziomu legislacji krajowej w tym zakresie. Potrzebne jest ustawowe zaliczenie „rolnictwa ekologicznego” do kategorii samodzielnego działania korzystającego ze wsparcia z EFRROW. Niezbędne jest również nowe rozporządzenie wykonawcze ministra określające szczegółowe warunki i tryb przyznawania pomocy finansowej dla tego działania. Ważne jest, aby to rozporządzenie nie stanowiło zbędnych, kazuistycznie uregulowanych barier utrudniających skorzystanie $\mathrm{z}$ tej formy pomocy. Należy również postulować ściślejsze powiązanie obu nurtów przepisów - o rolnictwie ekologicznym w ogólności i o płatności na rzecz rolnictwa ekologicznego. 


\section{LEGAL REGULATIONS OF ECOLOGICAL PRODUCTION IN POLISH AGRICULTURE}

Key words: ecological production, ecological agriculture, agri-environmental payment, ecological farm

Ecological agriculture, understood as agricultural production compliant with natural environment rules, in Poland is the subject of EU regulations and Polish legislation applied to incorporate provisions of the Common Agricultural Policy of EU. The ecological production method fulfills a double social role: on the one hand, it supplies goods to the specific market of ecological products; on the other hand, it is an activity conducted in public interest, as it facilitates environmental protection and development of rural areas. Depending on the social function of ecological agriculture that a given legal regulation focuses on, ecological agriculture regulations are divided into two groups. One may raise objections that the economic phenomena regulation is to detailed. Thus, in order to ensure its improvement, it is advisable to introduce the notion of an "ecological farm". 